\title{
The resurrection of Neohattoria Kamim. (Jubulaceae, Marchantiophyta): a six decade systematic conflict resolved through a molecular perspective
}

\author{
Juan Larraín', Benjamin Carter², Blanka Shaw ${ }^{2}$, Jörn Hentschel ${ }^{3}$, \\ Lynika S. Strozier', Tatsuwo Furuki ${ }^{4}$, Jochen Heinrichs, \\ Barbara Crandall-Stotler ${ }^{6}$, John Engel', Matt von Konrat'
}

I Science \& Education, The Field Museum, 1400 South Lake Shore Drive, Chicago, IL 60605-2496, U.S.A. 2 Department of Biology, Duke University, Durham, NC 27708-0338, U.S.A. 3 Department of Systematic Botany with Herbarium Haussknecht and Botanical Garden, Friedrich Schiller University, Fürstengraben 1, 07743 Jena, Germany 4 Natural History Museum \& Institute, 955-2 Aoba-cho, Chuo-ku, Chiba-shi, Chiba 260-8682, Japan 5 Ludwig-Maximilians-Universität München, Department für Biologie I, Systematische Botanik und Mykologie, GeoBio-Center, Menzinger Straße 67, 80638 München, Germany 6 Southern Illinois University, Department of Plant Biology, Mail Code 6509, wCarbondale IL 62901-6509, U.S.A.

Corresponding author: Juan Larrain (musgoschiloe@gmail.com)

Academic editor: E. Cooper | Received 20 March 2015 | Accepted 16 April 2015 | Published 16 June 2015

Citation: Larraín J, Carter B, Shaw B, Hentschel J, Strozier LS, Furuki T, Heinrichs J, Crandall-Stotler B, Engel J, von Konrat M (2015) The resurrection of Neohattoria Kamim. (Jubulaceae, Marchantiophyta): a six decade systematic conflict resolved through a molecular perspective. PhytoKeys 50: 101-122. doi: 10.3897/phytokeys.50.4940

\begin{abstract}
The systematic placement of Frullania herzogii has been contentious since its description six decades ago. Over the years it has been interpreted as either a member of the genus Frullania or segregated into its own genus, Neohattoria, due to morphological similarities with both Frullania and Jubula. Here we provide molecular evidence that supports the recognition of the genus Neohattoria and its inclusion within the Jubulaceae, together with Jubula and Nipponolejeunea. Jubulaceae are placed sister to Lejeuneaceae rather than to the monogeneric Frullaniaceae.
\end{abstract}

\section{Keywords}

DNA sequence data, Frullania, Frullaniaceae, Japan, Jubula, Jubulaceae, Lejeuneaceae, liverwort, Nipponolejeunea

Copyright Juan Larrain et al. This is an open access article distributed under the terms of the Creative Commons Attribution License (CC BY 4.0), which permits unrestricted use, distribution, and reproduction in any medium, provided the original author and source are credited. 


\section{Introduction}

The liverwort Frullania herzogii S.Hatt. was originally described by Hattori (1955) from a poor, sterile specimen collected on Mt. Hayachine in Iwate Prefecture, northern Honshu, Japan. Since that time the generic and even familial placement of the species has remained controversial. The species also has remained poorly known partially because of its seemingly limited distribution in the subalpine coniferous forest zones of Honshu and Hokkaido, Japan, and the Kuril Islands (Inoue et al. 1981, Stotler and Crandall-Stotler 1987). Hattori (1955) remarked that the leaf morphology, with acute teeth along the margin, differed from all the other Japanese Frullania Raddi species known by him. A few years later, in his monograph of Japanese Frullaniaceae, Kamimura (1961) erected the new genus Hattoria Kamim. to separate this taxon from other Frullania species. He stated that although his new genus superficially resembled species of Cololejeunea (Spruce) Schiffn. or Frullania, there was an important similarity between the branching patterns of Hattoria herzogii (S.Hatt) Kamim. and species in the genus Jubula Dumort. In both Jubula and Hattoria, the branches replace the lobule of the leaf at the point of insertion, and the leaf lobes are attached to both the main stem and to the branch. Although Kamimura (1961) noted the similarity of cell shape between Hattoria and Frullania, he considered the combination of branching architecture and leaf denticulation sufficient to recognize Hattoria as a distinct genus. A year later he had to give a new name, Neohattoria Kamim., to his recently described genus (Kamimura 1962), because of the almost simultaneous although earlier description of Hattoria by Schuster for a liverwort in the Lophoziaceae (Schuster 1961).

Later Schuster (1963), in a key for the Southern Hemisphere genera of liverworts, expanded the circumscription of Neohattoria to include two more species, Frullania microscopica Pearson from New Caledonia, and F. parhamii (R.M.Schust.) R.M.Schust. ex von Konrat, L.Söderstr. \& A.Hagborg from Fiji. He based his taxonomic decision on the morphology of the reduced leaves on branch bases, the subfloral innovations, and the sharply delimited bracts and bracteoles of F. microscopica, and on the toothed leaf lobes of this species. Schuster (1963) did not provide any argument for placement of the Fijian F. parhamii in Neohattoria, other than the hyaline margins of the leaves that can be seen in this species and in F. microscopica (as inferred from the key). However, his key is restricted to the Southern Hemisphere and did not include the type of the genus, which completely lacks a hyaline border in leaf lobes. Schuster (1970) later expanded this generic concept even further, including the Australasian F. rostrata (Hook.f. \& Taylor) Hook.f. \& Taylor ex Gottsche, Lindenb. \& Nees (as Neohattoria australis R.M.Schust.)

and $F$. hodgsoniae von Konrat, Braggins, Hentschel \& Heinrichs (as Neohattoria rostrata R.M.Schust.), the SE Asian F. junghubniana Gottsche var. tenella (Sande Lac.) Grolle \& S.Hatt. [as Neohattoria perversa (Steph.) R.M.Schust.], the New Caledonian $F$. chevalieri (R.M.Schust.) R.M.Schust. and $F$. neocaledonica J.J.Engel 
(as Neohattoria caledonica R.M.Schust.). Of these, F. hodgsoniae is now considered a member of $F$. subg. Diastaloba Spruce sect. Inconditum von Konrat, Hentschel $\&$ Heinrichs (von Konrat et al. 2010), while the rest of the taxa are currently included in Frullania subg. Microfrullania (R.M.Schust.) R.M.Schust. The current taxonomic placement of these taxa is based on both morphological (Hattori and Mizutani 1982, Schuster 1992) and molecular evidence (Hentschel et al. 2009, von Konrat et al. 2012).

Asakawa et al. (1979) demonstrated, based on chemical compound differences, that Jubulaceae sensu lato should be divided into three families, i.e. Jubulaceae, Frullaniaceae and Lejeuneaceae. This view has been confirmed by most molecular phylogenies published to date (e.g., Forrest et al. 2006, Heinrichs et al. 2005, 2007). Asakawa et al. (1979) listed 11 morphological characters that support the separation of Frullaniaceae and Jubulaceae, and placed Neohattoria together with Jubula in the Jubulaceae. Hattori $(1982,1984,1986)$ and Hattori and Mizutani (1982) also accepted the separation between Jubulaceae and Frullaniaceae and argued that Amphijubula R.M.Schust., a genus formerly considered by Schuster $(1970,1980)$ as intermediate between Jubula and Frullania, should be placed within Frullania. This view was first held by Engel (1978), who had earlier reduced Amphijubula to a synonym of Frullania.

In 1987, Stotler and Crandall-Stotler published a thorough treatise of the taxonomic history of Neohattoria herzogii (S.Hatt.) Kamim. in the context of a detailed re-evaluation of its morphology, including the discovery of immature female inflorescences. In that contribution they came to the conclusion that this taxon should be considered within the circumscription of Frullania, although in its own subgenus, $F$. subg. Dentatilobi Stotler \& Crand.-Stot. Their conclusion was based on both vegetative and reproductive characters, including the morphology of the bracts surrounding the female gametangia, lobule anatomy, leaf cell pattern, and the morphology of regenerants. Although they recognized that leaf-lobe insertion, branch morphology, and morphology of stylus are more similar to Jubula than to Frullania, they concluded that on the basis of the Frullania-like inflorescences and regenerants, Neohattoria should be synonomized with Frullania. This synonomy was adopted by Grolle and Meister (2004) who described a morphologically similar plant from Oligocene amber from Bitterfeld (Germany) as Frullania (subg. Dentatilobi) hamatosetacea Grolle. However, this fossil species appears morphologically closer to F. subg. Microfrullania than to Neohattoria, and this issue will be explored in detail in a forthcoming monograph of the latter subgenus.

Lack of useable specimens has previously precluded inclusion of Neohattoria in molecular phylogenetic studies. As a result of recent collecting activities, fresh material became available that allowed for successful DNA extraction and amplification. In the present study, we use molecular sequence data to investigate the phylogenetic position of Neohattoria. We investigate whether the genus should be placed in the Frullaniaceae or the Jubulaceae and evaluate whether molecular evidence supports the recognition of Neohattoria as a distinct genus. 


\section{Methods}

\section{Microscopy}

For the production of microscopic images an Olympus BX51 microscope was used, equipped with both a QICAM Fast1394 camera from QIMAGING (Surrey, Canada), and a slide scanner (moving platform stage attached between the objectives and the condenser) from Objective Imaging Ltd. (Cambridge, UK). The software "Surveyor" from the latter company was used for the digitally rendered images.

\section{DNA extraction, PCR amplification and sequencing}

We worked with two independent datasets to address two different questions, (1) what is the position of Neohattoria relative to the Frullaniaceae, Jubulaceae and Lejeuneaceae, and once we obtained results from these analyses, we asked (2) what is the position of Neohattoria within the Jubulaceae. For dataset 1 sequences were generated for two mitochondrial (nad1, rps3), and two chloroplast loci ( $p s b \mathrm{~A}, r b c \mathrm{~L}$ ), following DNA extraction, amplification and sequencing methods described by Shaw et al. (2003), and using primer sequences provided in Cooper et al. (2011). For dataset 2 we used the aforementioned plastid regions ( $p s b \mathrm{~A}$ and $r b c \mathrm{~L}$ ) together with the nuclear ITS region following the methods described by Shaw et al. (2003), and the chloroplast $\operatorname{trn} \mathrm{L}-\operatorname{trn} \mathrm{F}$ region, amplified and sequenced as described in von Konrat et al. (2012). All sequences were edited and manually aligned in PhyDE v0.9971 (www.phyde.de) following the alignment rules and hotspot definitions presented in Kelchner (2000), Olsson et al. (2009), and Borsch and Quandt (2009).

\section{Taxon sampling and outgroup selection}

For dataset 1 seven species of Radula were selected as outgroup taxa following the results already published in recent liverwort phylogenies (Davis 2004, Forrest et al. 2006, Feldberg et al. 2014, Heinrichs et al. 2005, 2007). The same criteria were undertaken for dataset 2, including all taxa with sequences available in GenBank for Jubula and Nipponolejeunea S. Hatt. (Ahonen 2006, Ahonen et al. 2003, Konstantinova and Vilnet 2011, Pätsch et al. 2010, Wilson et al. 2004, 2007), using selected taxa of the Lejeuneaceae and species of Frullania as outgroup based on results from dataset 1. GenBank accession numbers for both newly generated sequences and for already published sequences are provided in Appendices 1 and 2 for datasets 1 and 2 respectively.

\section{Phylogenetic inferences}

Both datasets were analysed with PartitionFinder v1.1.0 (Lanfear et al. 2012, 2014) to develop best-fit partitioning schemes and models of molecular evolution. Dataset 1 
was partitioned setting one separate data block for each of the four genes used, each of them divided in three according to each codon position; introns and/or spacers were coded as extra partitions. Dataset 2 was partitioned in four parts, corresponding to the regions included only, without inner codon partition for the coding regions analysed. For dataset 1, phylogenetic reconstructions under maximum likelihood (ML) were performed in GARLI v2.01 (Zwickl 2006), setting up seven different models for the eleven partitions determined by PartitionFinder. Two independent searches each with 100 bootstrap replicates were made, and the $50 \%$ majority-rule consensus tree from all obtained trees was obtained with SumTrees v3.3.1 included in the package DendroPy v3.12.2 (Sukumaran and Holder 2010). Bayesian Posterior Probabilities analyses (PP) were executed in MrBayes v3.2.2 (Huelsenbeck and Ronquist 2001, Ronquist and Huelsenbeck 2003) also with the partitioned data set as given by PartitionFinder, and setting a different model for the individual partitions from the available options in MrBayes, with all characters given equal weight and gaps treated as missing data. The default settings of the program for a priori probabilities were used. Four runs, each with four MCMC chains (one million generations each) were run simultaneously, with the temperature of the heated chain set to 0.2 (default setting). Chains were sampled every 100 generations. Calculation of the consensus tree and posterior probabilities of clades was based on the set of trees sampled after the chains had converged, as observed graphically using Tracer v1.5 (Rambaut and Drummond 2007). For dataset 2, phylogenetic reconstructions under ML were performed in GARLI v2.01 and Bayesian analyses were executed with MrBayes v3.2.2 following the protocols as described above. For this dataset only three different partitions were suggested by PartitionFinder, and the models given by this software for each partition were incorporated into the settings of both the ML and the Bayesian analysis. Trees were edited and support values added using TreeGraph v2.0.54-364 beta (Stöver and Müller 2010).

\section{Results}

The complete alignment for dataset 1 including all four regions mentioned above, with flanking areas pruned to avoid ambiguous readings, comprised 4818 characters for 54 accessions, of which 694 were parsimony informative. A total of 101 new sequences were generated for this study (Appendix 1). In the analysis of the Neohattoria sequences with accessions of the Frullaniaceae, Jubulaceae and Lejeuneaceae (dataset 1), Neohattoria is strongly supported (as defined by Pedersen et al. 2007) as one of three clades belonging to the Jubulaceae in both ML and Bayesian analyses, with accessions of Nipponolejeunea, resolved in a second clade and those of Jubula, in a third clade (Fig. 1), although the latter with low support $(\mathrm{ML}=52, \mathrm{PP}=0.6)$. The Jubulaceae is resolved as sister to the Lejeuneaceae with strong support in both types of analysis. The position of the Frullaniaceae as sister to this latter clade (Jubulaceae + Lejeuneaceae) was strongly supported by the Bayesian analyses $(\mathrm{PP}=1.0)$, but it was not recovered by the ML analyses. The Bayesian analyses also resolved Neohattoria as sister to the rest of the Jubulaceae (Nipponolejeunea + Jubula) with strong support $(\mathrm{PP}=1.0)$. 


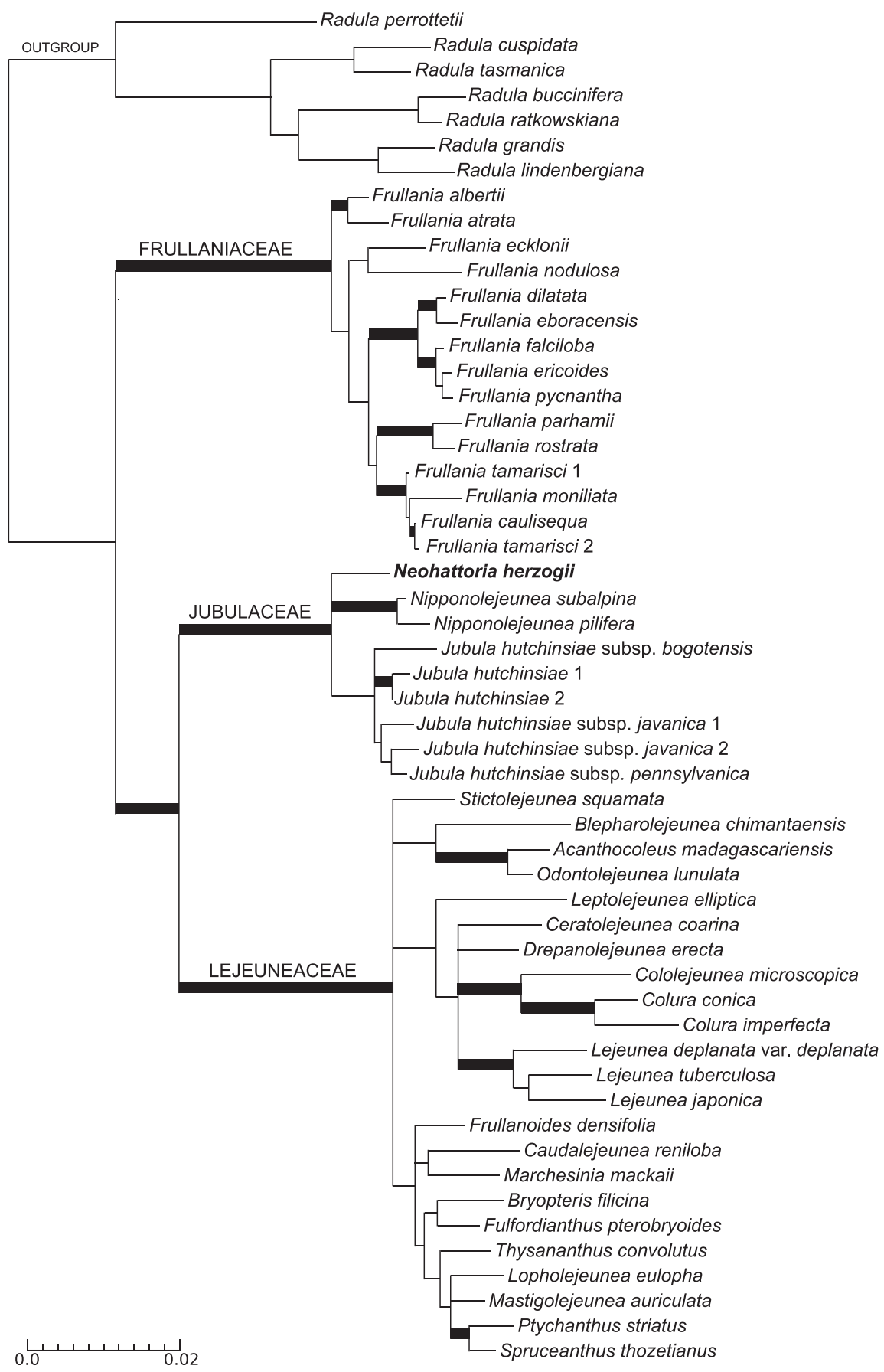

Figure I. Maximum likelihood (ML) tree showing the systematic position of Neohattoria relative to the Jubulaceae, Frullaniaceae and Lejeuneaceae. Wide black branches indicate ML bootstrap support > $90 \%$ and $\mathrm{PP}>0.95$. 


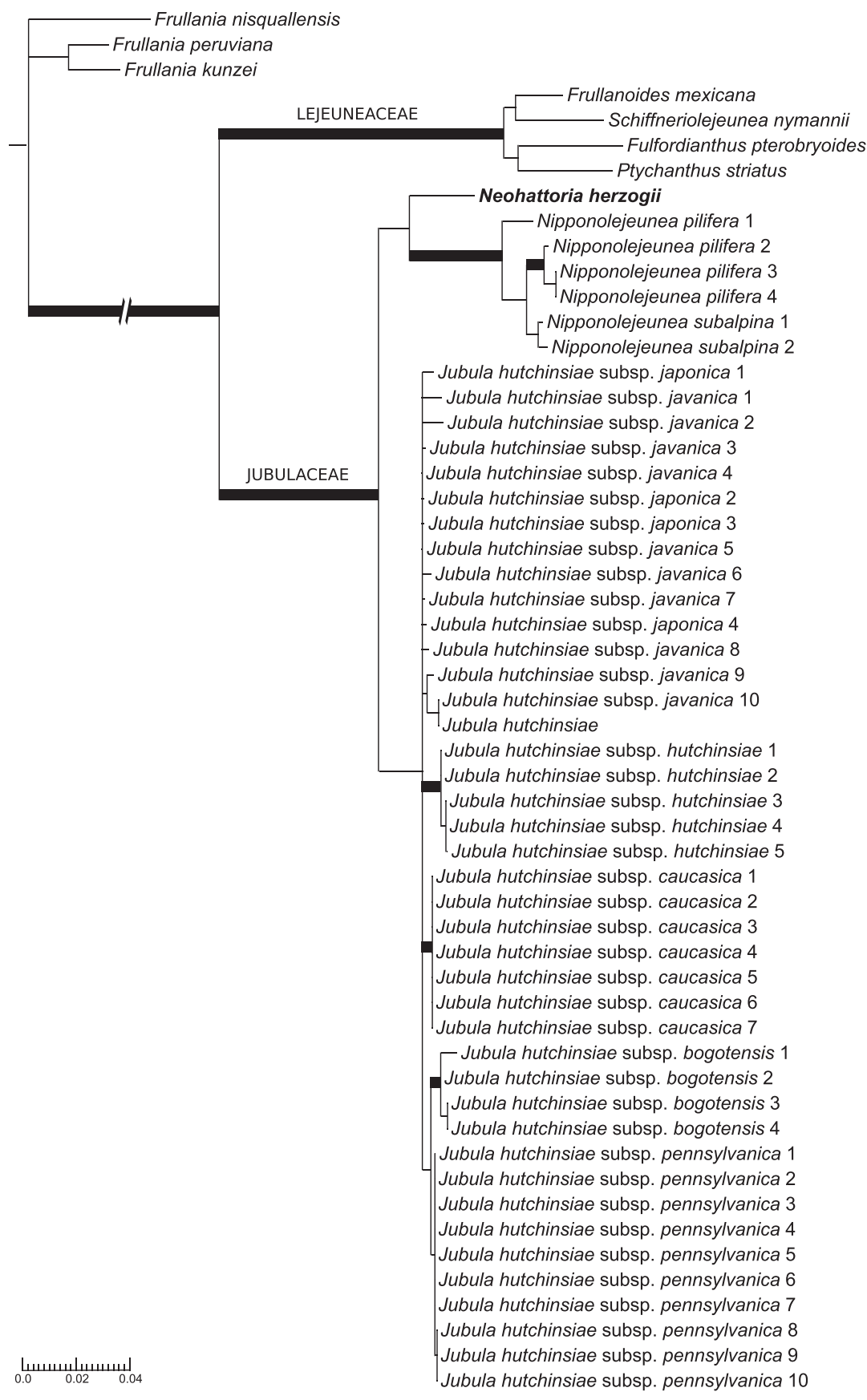

Figure 2. Maximum likelihood (ML) tree showing the systematic position of Neohattoria herzogii within the Jubulaceae. Only $1 / 2$ of the length of the branch between the Frullaniaceae and the Lejeuneaceae/ Jubulaceae clade is depicted. Wide black branches indicate ML bootstrap support $>90 \%$ and PP $>0.95$. 

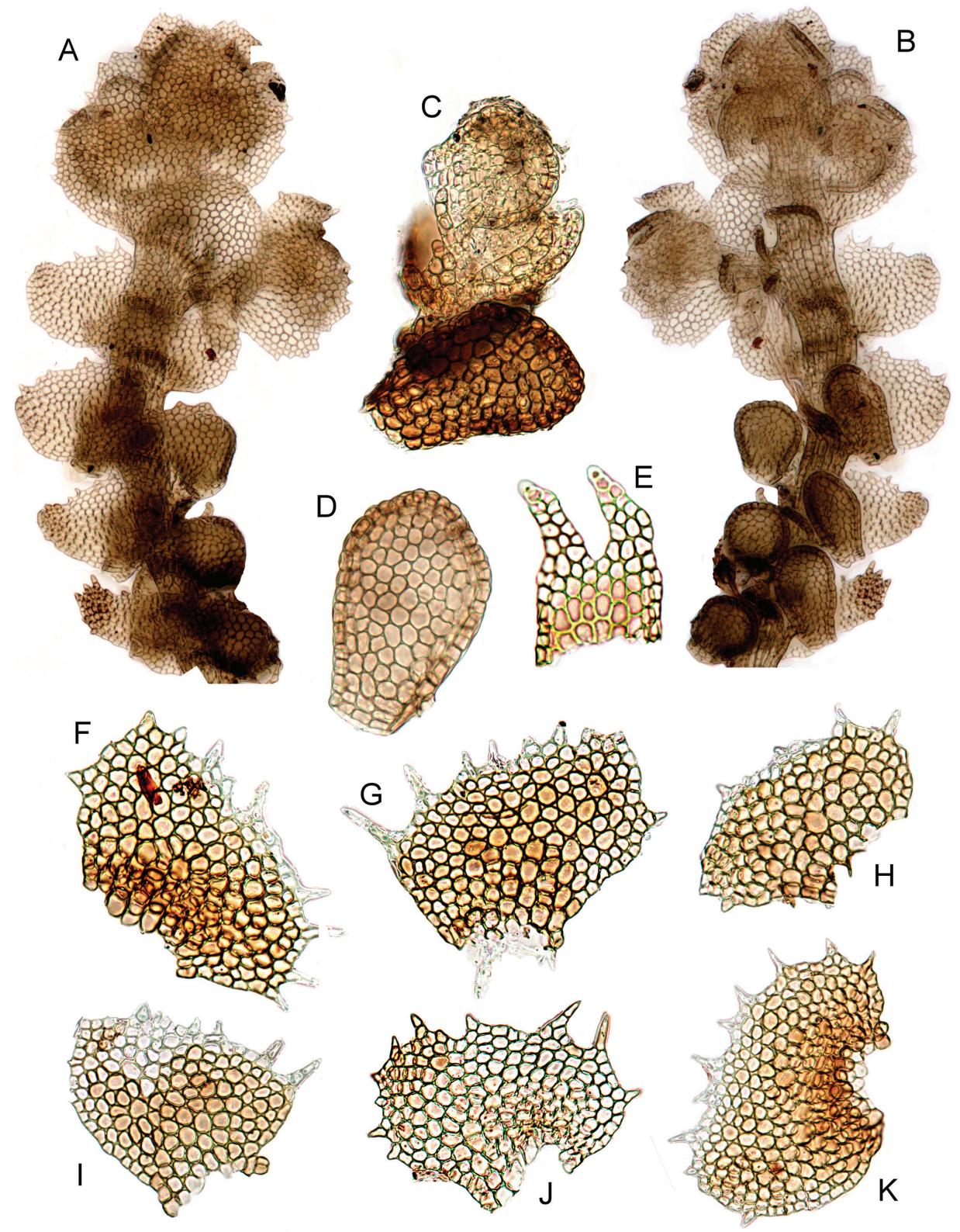

Figure 3. Neohattoria herzogii. A Habit, dorsal view B Habit, ventral view with distal lobules detached C Regenerant shoot originating from a detached lobule D Lobule E Underleaf F-K Leaves. All from Furuki 22673 (F). Scale bar: $350 \mu \mathrm{m}$ (A, B), $200 \mu \mathrm{m}$ (C), $180 \mu \mathrm{m}$ (D), $300 \mu \mathrm{m}$ (E), $150 \mu \mathrm{m}$ (F-K).

The complete alignment for dataset 2 including all four regions included, and after pruning the flanking areas to avoid ambiguous readings and deleting unalignable areas of the ITS region, comprised 3737 characters for 55 accessions, of which 548 were 
parsimony informative. The four different regions were not equally represented in the matrix, as shown in Appendix 2. The results of the analyses (Fig. 2) confirm with strong support the placement of Neohattoria within the Jubulaceae $(\mathrm{ML}=100, \mathrm{PP}=1.0)$, and forming a sister clade to Nipponolejeunea, although recovered with strong support only by the Bayesian analysis $(\mathrm{ML}=64, \mathrm{PP}=0.97)$. Jubula was resolved as the sister clade to the Neohattoria-Nipponolejeunea clade, although with low support $(\mathrm{ML}=65, \mathrm{PP}=0.5)$.

The voucher of Neohattoria herzogii used for DNA extraction is illustrated in Figure 3.

\section{Discussion}

Our molecular analyses support recognition of the genus Neohattoria as distinct from the genus Frullania, as first proposed by Kamimura (1961) almost 55 years ago. Moreover, our molecular analysis strongly supports its inclusion within the Jubulaceae, together with Jubula and Nipponolejeunea. A close relationship with Jubula, based on similarities in branch morphologies, was first suggested by Kamimura (1961, p. 94), and also accepted by Hattori et al. (1972). Inoue et al. (1981) provided new karyological, chemical and ecological data on $N$. herzogii and concluded that the biosystematic evidence collected suggested distance between Jubula and Neohattoria, but, nonetheless, retained Neohattoria in the Jubulaceae. While morphologically closer to Jubula than Nipponolejeunea to which it is sister, it is clearly not nested in the Jubula clade. This combination of molecular and morphological evidence, in fact, supports its recognition as a distinct genus in the Jubulaceae.

\section{Circumscription and relationships of the Jubulaceae}

Our results strongly support the position of the Jubulaceae (containing Jubula, Nipponolejeunea and Neohattoria) sister to the Lejeuneaceae, and the Frullaniaceae as sister of the latter clade, although without significant support (Fig. 1). These results agree with several molecular phylogenies (e.g. Ahonen 2004, Forrest et al. 2006, Heinrichs et al. 2005, 2007). Thus the traditional view of a widely circumscribed Jubulaceae including Frullania is further rejected in this study.

These three families (Frullaniaceae, Jubulaceae and Lejeuneaceae) share several morphological characters, including the leaves divided into two (or three) parts [lobe, lobule (and stylus)], the beaked perianths, the sporophyte enclosed in a stalked true calyptra, the bistratose capsule wall, and the vertically aligned elaters that are attached to the valve apices (Crandall-Stotler et al. 2009, Gradstein et al. 2001, Schuster 1992). However, these characters need to be carefully evaluated to understand their evolution and their role in demonstrating the history of these lineages. In the past, Jubula, Frullania and members of the Lejeuneaceae were placed in a single taxonomic group (the subtribe Jubuleae), based largely on the similarities among their sporophytes (e.g. Müller 1915). Verdoorn (1930) argued that based on most characters (e.g., number of archegonia, seta form, and 
lobule ontogeny) Jubula belongs nearest to Frullania, which later lead Schuster (1992, p. 6) to describe Jubula as a "bona-fide genus of Jubulaceae [= Frullaniaceae]". Mizutani (1961) was the first to propose that, except for the lobule structure, Jubula had no alignment with Frullania, and subsequently placed Jubula into the Lejeuneaceae. However, Asakawa et al. (1979) concluded that chemically, both Jubula and Frullania are quite different from Lejeunea Lib. species. Interestingly, the phylogenetic analysis by CrandallStotler and Stotler (2000) of 40 gametophyte and 21 sporophyte characters distributed among 34 liverwort families, resolved $F$. asagrayana Mont. as sister to a clade containing J. hutchinsiae (Hook.) Dumort. subsp. pennsylvanica (Steph.) Verd. and L. cavifolia (Ehrh.) Lindb. However, in the systematic treatment of the same work (Crandall-Stotler and Stotler 2000) Jubulaceae is presented as including both Jubula and Frullania, whereas the Lejeuneaceae is presented as a separate family, following accepted classifications of the time. The revised version of that classification, incorporating some recent molecular data, presents the Frullaniaceae, Jubulaceae and Lejeuneaceae as three separate families within the suborder Jubulineae (Crandall-Stotler et al. 2008, 2009), which is accepted here but with the transfer of Neohattoria from the Frullaniaceae to the Jubulaceae.

Assessing the importance of different morphological characters in circumscribing Frullaniaceae, Jubulaceae and Lejeuneaceae has been a difficult problem, but there are several characters that are consistent with the molecular phylogenetic results presented here. In most Lejeuneaceae a true stylus does not develop, but instead a single, unstalked slime papilla is formed at the junction of the lobule base and the stem, while in Jubula and Neohattoria there is a one- or two-celled filament terminated by a slime papilla in this position (Crandall-Stotler and Guerke 1980, Stotler and Crandall-Stotler 1987). Both types of structures are clearly different from those of the Frullaniaceae, where the stylus is always formed by more than two cells and is usually very conspicuous. The Jubulaceae and Frullaniaceae can be clearly differentiated from the Lejeuneaceae by the lobule, which is almost free from the larger dorsal lobe, and typically modified into an inflated, balloon-like to helmet-shaped sac whose aperture is directed either toward the shoot base or toward the stem, with the exception of Nipponolejeunea which has Lejeuneaceae-like lobules. Guerke (1978) hypothesised that Jubula was more advanced than Frullania on the basis that Jubula has many specialized characteristics e.g., a highly reduced stylus, seta, and foot, and features associated with the sporeling. In contrast, Schuster (1992, p. 9) stated that taxa such as Amphijubula microcaulis (Gola) R.M.Schust. (三F. microcaulis Gola), with a $16+4$ seriate seta and monogynous gynoecia, diminish the distinctions between the two groups such that he prefers not to attempt a "subfamilial separation" at all. However, revision of the chemical, morphological, and ecological data provided support for the recognition of two subfamilies in the Jubulaceae (Guerke 1978, von Konrat 2004). Alternatively, Asakawa et al. (1979), on the basis of biochemical and morphological evidence, proposed two families: Jubulaceae (Jubula, Neohattoria) and Frullaniaceae (Frullania, Steerea S.Hatt., Amphijubula, and Schusterella S.Hatt.). Hattori (1982, 1984, 1986) and Hattori and Mizutani (1982) also accepted two families. This approach has been adopted in most recent hepatic floras and classifications (Paton 1999, Damsholt 2002, Casas et al. 2009, Crandall-Stotler et al. 2009, Frey and Stech 2009). 
Schuster $(1980,1992)$ questioned the division into two families and argued that only the single family Jubulaceae should be recognized, but commented that this area of classification remains replete with ambiguities and contradictions. Interestingly, he also suggested that there was a possibility that Neohattoria might share a closer affinity to Jubulopsidaceae (= Lepidolaenaceae) than to Jubulaceae (Schuster 1996), a view first expressed when Grolle (1966) transferred Jubula novae-zelandiae E.A.Hodgs. \& S.W.Arnell, which is the generitype of Jubulopsis R.M.Schust., to Neohattoria. However, recent molecular analyses (e.g., Heinrichs et al. 2005, Forrest et al. 2006) have demonstrated that Jubulopsis (= Lepidolaena) is far removed from the Jubulaceae.

Morphologically, the monogeneric Frullaniaceae can be differentiated from the Jubulaceae by: (1) plants usually with conspicuous secondary pigmentation, often reddish; (2) initial leaves of branches either trifid or bifid; and (3) spores with rosette-like protrusions. Conversely, in the Jubulaceae the plants are: (1) soft and without secondary pigmentation (thus usually dull green to pale brown); (2) the initial leaves of branches are small, subtriangular, and never tri- or bifid; and (3) the spores without rosettelike protrusions. The first two of these characters support the placement of Neohattoria within Jubulaceae rather than Frullaniaceae (spores remain unknown in Neohattoria).

Chemically, Frullania species in general, produce significant amounts of sesquiterpene lactones, diterpenoids, and bibenzyl derivatives, which are considered important chemosystematic markers of the group (Asakawa et al. 1981, 1983, 1987, Kraut et al. 1994). On the other hand, cyclocolorenone and maalioxide have been isolated as major components of Jubula hutchinsiae (Hook.) Dumort. subsp. japonica (Steph.) Horik. \& Ando (Asakawa et al. 1979); interestingly cyclocolorenone is also widely distributed in the Porellaceae. In contrast, no members of Jubula or Frullania produce paraffinic hydrocarbons which are characteristic for Neohattoria (Inoue et al. 1981).

Interestingly, Schuster (1996) suggested that there was a possibility that Neohattoria might share a closer affinity to Jubulopsidaceae (= Lepidolaenaceae) than to Jubulaceae. This view was first expressed when Grolle (1966) transferred Jubula novae-zelandiae E.A.Hodgs. \& S.W.Arnell, which is the type species of Jubulopsis R.M.Schust., to Neohattoria. However, preliminary unrooted trees made for this contribution including Ascidiota C.Massal., Gackstroemia Trevis., Goebeliella Steph., Lepidogyna R.M.Schust., Lepidolaena Dumort. (= Jubulopsis) and Porella L. together with representatives outside the Porellales, showed Neohattoria far away from Lepidolaenaceae but within Jubulaceae (results not depicted). These results are basically the same as the ones observed in recent molecular phylogenies (e.g. Heinrichs et al. 2005, Forrest et al. 2006), demonstrating that these groups are only distantly related to either the Jubulaceae or the Frullaniaceae.

\section{Circumscription and relationships of Neohattoria}

Our results place Neohattoria in the Jubulaceae with strong support, together with Nipponolejeunea and Jubula. Within the Jubulaceae, Neohattoria is resolved as sister to Nipponolejeunea, and this latter clade sister to Jubula, although this relationship is sen- 
sitive to taxon sampling (cf. Figs. 1 and 2), and not strongly supported in the analyses. When describing the genus Hattoria (later renamed Neohattoria), Kamimura (1961) conceived it as a monotypic genus containing only the Japanese endemic $N$. herzogii. The singularity of this taxon was well described and illustrated, highlighting its closer affinities to Jubula instead of Frullania, mostly because of its branching pattern and leaf insertion: "[...] the branch replaces the lobule of leaf in origin and the lobe is inserted partly to the stem and partly to the branch. The first leaf and underleaf of branches are much deformed, being the "Vorblätter" of Verdoorn (1930)." (Kamimura 1961, p. 94). The characteristic combination of traits that led Kamimura to describe this new genus vanished when Schuster $(1963,1970)$ added more species in the circumscription of Neohattoria as explained above. Schuster (1970) still recognized the taxonomic singularity of $N$. herzogii when placing it in its own subgenus within Neohattoria, but failed to see the relationships of this taxon with other Jubula species, precisely because of his wide concept of Neohattoria that includes members of F. subg. Microfrullania and F. subg. Diastaloba.

Oil-bodies in Neohattoria are homogenous, usually more than ten per cell, and similar in size to chloroplasts (Hattori et al. 1972, Inoue et al. 1981). Hattori et al. (1972) reported 10-20 oil-bodies per leaf lobe median cell for $N$. herzogii and later Inoue et al. (1981, p. 25) reported a similar number "usually 7-15 per leaf-lobe cell (rarely up to 22)". Hattori et al. (1972) stated that oil-bodies of Neohattoria are hyaline and homogenous, and Inoue et al. (1981) recorded in their specimen of Neohattoria that the oil-bodies were completely colourless and homogenous. However, they noted that sometimes they were faintly papillose with a few distinct granules; Inoue et al. (1981) were uncertain if this was due to degeneration of the oil-bodies. Reports of oil-body numbers for Jubula are ambiguous: although Guerke (1979) and Paton (1999) suggested they range between 3-7 in all Jubula taxa, Schuster (1992) stated that the oil-bodies are numerous in the North American material of J. pennsylvanica (三 J. hutchinsiae subsp. pennsylvanica), ranging from 6-16 per cell, and Mizutani (1961) reported 2-10 for Japanese Jubula. All authors agree that the oil-bodies in Jubula are faintly granular or homogeneous. In Nipponolejeunea, on the other hand, the oil-bodies range between 3-5(7) per cell, are hyaline to somewhat grayish, and are formed by 15-20 internal oil-globules (Mizutani 1961). In Frullania the oil-bodies are usually larger, finely to coarsely papillose rather than smooth, and few per cell, with their number generally increasing from the leaf-lobe marginal cells to the basal cells, except in the species that have basal ocelli; however, this number rarely reaches the number of oil-bodies seen in Neohattoria or Jubula. The average number of oil-bodies from the 22 species studied by von Konrat (2004) is 4.3 per median lobe cell. One remarkable exception is the North American species F. stylifera (R.M.Schust.) R.M.Schust., which has up to 16 oil-bodies per median cell (von Konrat 2004). A survey of over sixty species (including literature data) suggests that this is a rare condition in the genus (von Konrat 2004). Schuster (1992) described the oil-bodies of Frullania as formed of numerous oil-globules and usually appearing coarsely to finely papillose, the only exception being the oil-bodies of $F$. subg. Microfrullania, which are smooth and frequently 
appear as almost homogeneous oil-droplets (von Konrat 2004). The oil-bodies of Neohattoria then appear closer to the other Jubulaceae genera in appearence (although smooth, homogeneous oil-bodies are also seen in Frullania subg. Microfrullania) and number, notwithstanding the number reported for Nipponolejeunea and some reports of Jubula taxa with fewer oil-body numbers.

\section{Nomenclatural novelties}

Neohattoria Kamim., Journal of Japanese Botany 37: 218. 1962.

$\equiv$ Frullania subg. Dentatilobi Stotler \& Crand.-Stotl., Memoirs of The New York Botanical Garden 45: 542.1987 ("Dentatiloba"). syn.nov. - Type: Frullania herzogii S.Hatt.

\section{Acknowledgements}

We thank Anders Hagborg (The Field Museum) and Lars Söderström (Norwegian University of Science and Technology) and the Early Land Plants Today (ELPT) project for access to nomenclatural data. Support from the Biodiversity Synthesis Center of the Encyclopedia of Life provided important funding to help foster international initiatives. The Biodiversity Heritage Library is acknowledged for the facility they provide that has greatly accelerated our effort. The generous support by the National Science Foundation (Awards No. 1145898, 1146168, and 0531730) is gratefully acknowledged. We also recognize the support of the Museum Collection Spending Fund, administered by The Field Museum, as well as curatorial support provided by Yarency Rodriguez, Lucia Kawasaki and Anna Balla (The Field Museum). Lauren Smith is acknowledged for providing the digital images used to compile the plates. Finally, we thank Matt Renner and an anonymous reviewer for their help in improving the manuscript.

\section{References}

Ahonen I (2004) Molecular phylogeny of liverwort order Porellales (Marchantiophyta, Jungermanniopsida). In: Goffinet B, Hollowell VC, Magill R (Eds) Molecular Systematics of Bryophytes. Monographs in Systematic Botany from the Missouri Botanical Garden 98: $169-188$.

Ahonen I (2006) The taxonomic position of the genus Nipponolejeunea Hatt. Journal of the Hattori Botanical Laboratory 99: 319-342.

Ahonen I, Muona J, Piippo S (2003) Inferring the phylogeny of the Lejeuneaceae (Jungermannipsida): a first appraisal of molecular data. The Bryologist 106: 297-308. doi: 10.1639/0007-2745(2003)106[0297:ITPOTL]2.0.CO;2 
Asakawa Y, Tokunaga N, Toyota M, Takemoto T, Hattori S, Mizutani M, Suire C (1979) Chemosystematics of bryophytes II. The distribution of terpenoids in Hepaticae and Anthocerotae. Journal of the Hattori Botanical Laboratory 46: 67-76.

Asakawa Y, Matsuda R, Toyota M, Hattori S, Ourisson G (1981) Terpenoids and bibenzyls of 25 liverwort Frullania species. Phytochemistry 20: 2187-2194. doi: 10.1016/00319422(81)80111-2

Asakawa Y, Matsuda R, Toyota M, Takemoto T, Connolly JD, Phillips WR (1983) Sesquiterpenoids from Chiloscyphus sp., Clasmatocolea sp., and Frullania sp. Phytochemistry 22: 961-964. doi: 10.1016/0031-9422(83)85030-4

Asakawa Y, Matsuda R, Cheminat A (1987) Bibenzyl derivatives from Frullania species. Phytochemistry 26: 1117-1122. doi: 10.1016/S0031-9422(00)82361-4

Borsch T, Quandt D (2009) Mutational dynamics and phylogenetic utility of noncoding chloroplast DNA. Plant Systematics and Evolution 282: 169-199. doi: 10.1007/s00606-009-0210-8

Casas C, Brugués M, Cros RM, Sérgio C, Infante M (2009) Handbook of liverworts and hornworts of the Iberian Peninsula and the Balearic Islands. Ilustrated keys to genera and species. Institut d'Estudis Catalans, Secció de Ciències Biològiques, Barcelona, 177 pp.

Cooper ED, Shaw AJ, Shaw B, Henwood MJ, Heslewood MM, Brown EA (2011) A multi-locus molecular phylogeny of the Lepidoziaceae: Laying the foundations for a stable classification. Molecular Phylogenetics and Evolution 59: 489-509. doi: 10.1016/j. ympev.2011.02.006

Crandall-Stotler B, Guerke WR (1980) Developmental anatomy of Jubula Dum. (Hepaticae). Bryologist 83: 179-201. doi: 10.2307/3242131

Crandall-Stotler B, Stotler RE (2000) Morphology and classification of the Marchantiophyta. In: Shaw AJ, Goffinet B (Eds) Bryophyte biology. Cambridge University Press, Cambridge, 21-70. doi: 10.1017/CBO9781139171304.003

Crandall-Stotler B, Stotler RE, Long DG (2008) Morphology and classification of the Marchantiophyta. In: Goffinet B, Shaw AJ (Eds) Bryophyte biology, second edition. Cambridge University Press, Cambridge, 1-54.

Crandall-Stotler B, Stotler RE, Long DG (2009) Phylogeny and classification of the Marchantiophyta. Edinburgh Journal of Botany 66: 155-198. doi: 10.1017/S0960428609005393

Damsholt K (2002) Illustrated flora of Nordic liverworts and hornworts. Nordic Bryological Society, Lund, 837 pp.

Davis EC (2004) A molecular phylogeny of leafy liverworts (Jungermanniidae: Marchantiophyta). Monographs in Systematic Botany from the Missouri Botanical Garden 98: 87-118.

Engel JJ (1978) A taxonomic and phytogeographic study of Brunswick Peninsula (Strait of Magellan) Hepaticae and Anthocerotae. Fieldiana Botany 41: 1-319. doi: 10.5962/bhl. title. 2426

Feldberg K, Schneider H, Stadler T, Schäfer-Verwimp A, Schmidt A, Heinrichs J (2014) Epiphytic leafy liverworts diversified in angiosperm-dominated forests. Scientific Reports 4: 5974. doi: 10.1038/srep05974

Forrest LL, Davis EC, Long DG, Crandall-Stotler BJ, ClarkA, Hollingsworth ML(2006) Unraveling the evolutionary history of the liverworts (Marchantiophyta): multiple taxa, genomes 
and analyses. The Bryologist 109: 303-334. doi: 10.1639/0007-2745(2006)109[303:UT EHOT]2.0.CO;2

Frey W, Stech M (2009) Marchantiophyta. In: Frey W (Ed.) Syllabus of plant families - A. Engler's Syllabus der Pflanzenfamilien. part 3: Bryophytes and seedless vascular plants. 13th edition, viii, Borntraeger, Berlin/Stuttgart, 13-115.

Gradstein SR, Churchill SP, Salazar-Allen N (2001) Guide to the bryophytes of tropical America. Memoirs of the New York Botanical Garden 86: 1-577.

Grolle R (1966) Miscellanea hepaticologica (51-60). Journal of Japanese Botany 41: 141-147. Grolle R, Meister K (2004) The liverworts in Baltic and Bitterfeld amber. Weissdorn, Jena, 1-91. Guerke WR (1978) A monograph of the genus Jubula Dumortier. Bryophytorum Biblioteca 17: $1-118$.

Hattori S (1955) A remarkable Frullania species from northern Japan. Feddes Repertorium Specierum Novarum Regni Vegetabilis 58: 53-54.

Hattori S (1982) A synopsis of New Guinean Frullania, Hepaticae. Journal of the Hattori Botanical Laboratory 51: 203-271.

Hattori S (1984) New Caledonian Frullaniaceae. Journal of the Hattori Botanical Laboratory 57: 405-426.

Hattori S (1986) A synopsis of New Caledonian Frullaniaceae. Journal of the Hattori Botanical Laboratory 60: 203-237.

Hattori S, Mizutani M (1982) A status of Amphijubula (Hepaticae) with special reference to the seta anatomy. Journal of the Hattori Botanical Laboratory 52: 441-448.

Hattori S, Sharp AJ, Mizutani M (1972) Schusterella, a new genus of Jubulaceae (Hepaticae). Journal of Japanese Botany 20: 329-338.

Heinrichs J, Gradstein SR, Wilson R, Schneider H (2005) Towards a natural classification of liverworts (Marchantiophyta) based on the chloroplast gene $r b c$ L. Cryptogamie, Bryologie 26: 215-233.

Heinrichs J, Hentschel J, Wilson R, Feldberg K, Schneider H (2007) Evolution of leafy liverworts (Jungermanniidae, Marchantiophyta): estimating divergence times from chloroplast DNA sequences using penalized likelihood with integrated fossil evidence. Taxon 56: 31-44.

Hentschel J, von Konrat MJ, Pócs T, Schäfer-Verwimp A, Shaw AJ, Schneider H, Heinrichs J (2009) Molecular insights into the phylogeny and subgeneric classification of Frullania Raddi (Frullaniaceae, Porellales). Molecular Phylogenetics and Evolution 52: 142-156. doi: 10.1016/j.ympev.2008.12.021

Holmgren PK, Holmgren NH, Barnett LC (1990) Index herbariorum. Part I: The herbaria of the world (Regnum Veg. 120), eighth edition. New York Botanical Garden, New York, $693 \mathrm{pp}$.

Huelsenbeck JP, Ronquist F (2001) MrBayes: Bayesian inference of phylogeny. Bioinformatics 17: 754-755. doi: 10.1093/bioinformatics/17.8.754

Inoue H, Asakawa Y, Gradstein SR (1981) A biosystematic study of Neohattoria herzogii (Hatt.) Kamim. Bulletin of the National Science Museum, Tokyo, Series B, 7: 23-30.

Kamimura M (1961) A monograph of Japanese Frullaniaceae. Journal of the Hattori Botanical Laboratory 24: 1-109. 
Kamimura M (1962) On the genus Neohattoria Kamim. nom. nov. (Hepaticae). Journal of Japanese Botany 37: 26.

Kelchner SA (2000) The evolution of non-coding chloroplast DNA and its application in plant systematics. Annals of the Missouri Botanical Garden 87: 482-498. doi: 10.2307/2666142

Konstantinova NA, Vilnet AA (2011) Jubula hutchinsiae subsp. caucasica subsp. nov. (Jubulaceae, Marchantiophyta) - a new taxon from the western Caucasus. Arctoa 20: 227-238. doi: 10.15298/arctoa.20.18

Kraut L, Mues R, Sim-Sim M (1994) Sesquiterpene lactones and 3-benzylphthalides from Frullania muscicola. Phytochemistry 37: 1337-1346. doi: 10.1016/S0031-9422(00)90409-6

Lanfear R, Calcott B, Ho SYW, Guindon S (2012) PartitionFinder: combined selection of partitioning schemes and substitution models for phylogenetic analyses. Molecular Biology and Evolution 2: 1695-1701. doi: 10.1093/molbev/mss020

Lanfear R, Calcott B, Kainer D, Mayer C, Stamatakis A (2014) Selecting optimal partitioning schemes for phylogenomic datasets. BMC Evolutionary Biology 14: 82. doi: 10.1186/1471-2148-14-82

Mizutani M (1961) A revision of Japanese Lejeuneaceae. Journal of the Hattori Botanical Laboratory 24: 115-302.

Müller K (1915) Die Lebermoose Deutschlands, Oesterreichs u. d. Schweiz mit Berücksichtigung der übrigen Länder Europas, II. Abteilung. In: Dr. L. Rabenhorst's KryptogamenFlora von Deutschland, Oesterreich und der Schweiz. 2. Auflage, 6. Band, 24. Lieferung. Eduard Kummer, Leipzig, 593-656.

Olsson S, Buchbender V, Enroth J, Hedenäs L, Huttunen S, Quandt D (2009) Phylogenetic analyses reveal high levels of polyphyly among pleurocarpous lineages as well as novel clades. The Bryologist 112: 447-466. doi: 10.1639/0007-2745-112.3.447

Paton JA (1999) The liverwort flora of the British Isles. Harley Books, Colchester, 626 pp.

Pätsch R, Hentschel J, Linares-Palomino R, Zhu R-L, Heinrichs J (2010) Diversification and taxonomy of the liverwort Jubula Dumort. (Jungermanniopsida: Porellales) inferred from nuclear and chloroplast DNA sequences. Systematic Botany 35: 6-12. doi: $10.1600 / 036364410790862515$

Pedersen N, Holyoak DT, Newton AE (2007) Systematics and morphological evolution within the moss family Bryaceae: A comparison between parsimony and Bayesian methods for reconstruction of ancestral character states. Molecular Phylogenetics and Evolution 43: 891-907. doi: 10.1016/j.ympev.2006.10.018

Rambaut A, Drummond AJ (2007) Tracer, version 1.4. http://beast.bio.ed.ac.uk/Tracer

Ronquist F, Huelsenbeck JP (2003) MRBAYES 3: Bayesian phylogenetic inference under mixed models. Bioinformatics 19: 1572-1574. doi: 10.1093/bioinformatics/btg180

Schuster RM (1961) Studies in Lophoziaceae. I. The genera Anastrophyllum and Sphenolobus and their segregates. Revue Bryologique et Lichénologique 30: 55-73.

Schuster RM (1963) Studies on antipodal Hepaticae. I. Annotated key to the genera of antipodal Hepaticae with special reference to New Zealand and Tasmania. Journal of the Hattori Botanical Laboratory 26: 185-309.

Schuster RM (1970) Studies on antipodal hepaticae, III. Jubulopsis Schuster, Neohattoria Kamimura and Amphijubula Schuster. Journal of the Hattori Botanical Laboratory 33: 266-304. 
Schuster RM (1980) New combinations and taxa of Hepaticae, I. Phytologia 45: 415-437.

Schuster RM (1992) The Hepaticae and Anthocerotae of North America east of the hundredth meridan. Volume V. Field Museum of Natural History, Chicago, 854 pp.

Schuster RM (1996) On Jubulopsis Schust. (Jungermanniales: Jubulopsidaceae fam. nov.) and its relationships. Journal of Bryology 19: 297-310.

Shaw AJ, Cox CJ, Boles SB (2003) Polarity of peatmoss evolution: who says mosses have no roots? American Journal of Botany 90: 1777-1787. doi: 10.3732/ajb.90.12.1777

Stotler RE, Crandall-Stotler B (1987) A re-evaluation of the genus Neohattoria (Jubulaceae). Memoirs of the New York Botanical Garden 45: 535-543.

Stöver BC, Müller KF (2010) TreeGraph 2: Combining and visualizing evidence from different phylogenetic analyses. BMC Bioinformatics 11: 7. doi: 10.1186/1471-2105-11-7

Sukumaran J, Holder MT (2010) DendroPy: A Python library for phylogenetic computing. Bioinformatics 26: 1569-1571. doi: 10.1093/bioinformatics/btq228

Verdoorn F (1930) Die Frullaniaceae der Indomalesischen Inseln. (De Frullaniaceis VII). Annales Bryologici Supplmentary Volume 1: 1-188. doi: 10.1007/978-94-015-5385-8

von Konrat M (2004) A systematic study of the liverwort genus Frullania Raddi: encompassing a worldwide monograph of subg. Microfrullania (Schust.) Schust.; a revision of the New Zealand species \& study of subsidiary species. PhD dissertation, The University of Auckland, NZ, xxviii +408 pp.

von Konrat M, Hentschel J, Heinrichs J, Braggins JE, Pócs T (2010) Forty-one degrees below and sixty years in the dark: Frullania sect. Inconditum, a new section of Australasian Frullania species including F. colliculosa, sp. nov., F. hodgsoniae, nom. and stat. nov., F. aterrima, and $F$. hattorii (Frullaniaceae, Marchantiophyta). Nova Hedwigia 91: 471-500. doi: 10.1127/0029-5035/2010/0091-0471

von Konrat M, de Lange P, Greif M, Strozier L, Hentschel J, Heinrichs J (2012) Frullania knightbridgei, a new liverwort (Frullaniaceae, Marchantiophyta) species from the deep south of Aotearoa-New Zealand based on an integrated evidence-based approach. PhytoKeys 8: 13-36. doi: 10.3897/phytokeys.8.2496

Wilson R, Gradstein SR, Heinrichs J, Groth H, Ilkiu-Borges AL, Hartmann FA (2004) Phylogeny of Lejeuneaceae: a cladistic analysis of chloroplast $r b c \mathrm{~L}$ sequences and morphology with preliminary comments on the mithocondrial nad4-2 spacer region. In: Goffinet B, Hollowell VC, Magill RE (Eds) Molecular Systematics of Bryophytes. Monographs in Systematic Botany from the Missouri Botanical Garden 98: 189-202.

Wilson R, Gradstein SR, Schneider H, Heinrichs J (2007) Unravelling the phylogeny of Lejeuneaceae (Jungermanniopsida): Evidence for four main lineages. Molecular Phylogenetics and Evolution 43: 270-282. doi: 10.1016/j.ympev.2006.10.017

Zwickl DJ (2006) GARLI (Genetic Algorithm for Rapid Likelihood Inference). Version 2.01. http://www.bio.utexas.edu/faculty/antisense/garli/garli.html 


\section{Appendix I}

Voucher information for data set 1. Information is presented in the following order: taxon name, collector followed by collection number (herbarium acronyms follow Holmgren et al. 1990), country: region (if known), GenBank accesion numbers ( $p s b \mathrm{~A} /$ $r b c \mathrm{~L} / r p s 3 /$ nad 1$)$. Lacking sequences are indicated by a dash (-). New sequences generated for this study are marked by an asterisk $\left({ }^{*}\right)$.

Acanthocoleus madagascariensis (Steph.) Kruijt, Pócs 97145/AA (GOET), Uganda, EF011843/DQ983649/_/_; Blepharolejeunea chimantaensis van Slageren \& Kruijt, Pócs \& Rico 00234/A (F), Venezuela, KF851876/_/_/KF852465; Bryopteris filicina (Sw.) Nees, Churchill, Magombo \& Price 19855 (NY), Bolivia, AY607930/ DQ439681/KF851576/KF852481; Caudalejeunea reniloba (Gottsche) Steph., Pócs et al. 01090/AB (F), Australia, KF851845/KF852294/KF851541/KF852441; Ceratolejeunea coarina (Gottsche) Schiffn., Zartman 1235.1 (DUKE), Brazil, AY607934/ AY608026/_/KF852489; Cololejeunea microscopica (Taylor) Schiffn., Long \& Rothero 37789 (E), Scotland: Wester Ross, KF851954/KF852386/KF851651/KF852552; Colura conica (Sande Lac.) K.I.Goebel, Pócs \& Streimann 9986/W (F), Australia: Queensland, KM817490*/KM817513*/KM817536*/KM817462*; Colura imperfecta Steph., Pócs \& Pócs 07019/A (F), Thailand, KF851881/KF852327/_/KF852469; Drepanolejeunea erecta (Steph.) Mizut., Long 28691 (E), Bhutan, JF513393/ JF513452/KF851515/JF513342; Frullania albertii Steph., Davis 295 (DUKE), Ecuador, AY607942/DQ439685/KM817549*/KM817477*; Frullania atrata (Sw.) Nees ex Mont., Dauphin 3306 (F), Costa Rica, KM817491*/—/KM817540*/KM817466*; Frullania caulisequa (Nees) Mont., Karst, Shaw \& Gibbs 022 (DUKE), USA: North Carolina, KM817500*/KM817526*/KM817553*/KM817481*; Frullania dilatata (L.) Dumort., Stotler 4666 (SIU), Portugal, KM817502*/KM817528*/KM817555*/ KM817482*; Frullania eboracensis Lehm., Stotler 80-4354 (ABSH), USA: Illinois, AY688827/AY688779/KM817547*/KM817475*; Frullania ecklonii (Spreng.) Spreng. ex Gottsche, Lindenb. \& Nees, Pócs 02030/W (F), Kenya, KM817488*/ KM817510*/KM817533*/KM817459*; Frullania ericoides (Nees) Mont., Long 35167 (E), China: Yunnan, KM817486*/KM817507*/KM817531*/KM817456*; Frullania falciloba Taylor ex Lehm., Engel, von Konrat \& Braggins 26837 (F), New Zealand, KM817489*/KM817511*/KM817534*/KM817460*; Frullania moniliata (Reinw., Blume \& Nees) Mont., Mizutani s.n. (ABSH), Japan, AY507484/AY507401/ KM817548*/KM817476*; Frullania nodulosa (Reinw., Blume \& Nees) Nees, Pócs \& Pócs 03261/A (F) Fiji, KM817492*/KM817517*/KM817541*/KM817467*; Frullania parhamii (R.M.Schust.) R.M.Schust. ex von Konrat, L.Söderstr. \& A.Hagborg, von Konrat, Braggins \& Naikatini 6/16-5 (F), Fiji, _/KM817516*/KM817539*/ KM817465*; Frullania pycnantha (Hook.f. \& Taylor) Taylor ex Gottsche, Lindenb. \& Nees, von Konrat 99/409 (F), New Zealand, KM817499*/KM817525*/_/ KM817480*; Frullania rostrata (Hook.f. \& Taylor) Hook.f. \& Taylor ex Gottsche, Lindenb. \& Nees, Engel, von Konrat \& Braggins 27770 (F), New Zealand, —/ KM817512*/KM817535*/KM817461*; Frullania tamarisci (L.) Dumort. 1, Stot- 
ler 4661 (SIU), Portugal: Sintra, KM817501*/KM817527*/KM817554*/—; Frullania tamarisci 2, Long 35371 (E), France, KM817487*/KM817508*/KM817532*/ KM817457*; Frullanoides densifolia Raddi, Gradstein 10171 (GOET), Ecuador, KF851930/KF852371/KF851634/KF852530; Fulfordianthus pterobryoides (Spruce) Gradst., Gradstein \& Varon 11069 (GOET), Colombia, KF851931/KF852372/ KF851635/KF852531; Jubula hutchinsiae (Hook.) Dumort. 1, Long 29077 (E), UK: England, -/KM817509*/_KM817458*; Jubula hutchinsiae 2, Drehwald 3007 (GOET), Portugal, EF011746/AY548101/—/—; Jubula hutchinsiae subsp. bogotensis (Steph.) Verd., Gradstein s.n. (GOET), Mexico, EF011758/AY548100/_/_; Jubula hutchinsiae subsp. javanica (Steph.) Verd. 1, Konstantinova \& Savchenko K479/107 (F), Russia, —/KM817506*/KM817542*/KM817468*; Jubula hutchinsiae subsp. javanica 2, Kodama s.n. (ABSH), Japan: Wakayama Pref., AY507492/AY507408/ KF851585/JF513366; Jubula hutchinsiae subsp. pennsylvanica (Steph.) Verd., Risk 11005 (DUKE), USA, AY607954/KM817523*/KM817550*/—; Lejeunea deplanata Nees var. deplanata, Shaw F533 (DUKE), USA: North Carolina, KM817498*I KM817524*/KM817552*/KM817479*; Lejeunea japonica Mitt., Bakalin s.n. (F), Russia, -/KM817518*/KM817543*/KM817469*; Lejeunea tuberculosa Steph., Long 28596 (E), Bhutan, JF513394/JF513453/KF851518/JF513344; Leptolejeunea elliptica (Lehm.) Besch., Yamaguchi s.n. (F), Japan, KM817485*/KM817515*/ KM817538*/KM817464*; Lopholejeunea eulopha (Taylor) Schiffn., Pócs et al. 08036/U (F), Fiji, KF851868/KF852314/_/—; Marchesinia mackaii (Hook.) Gray, Buryova 2181 (DUKE), UK: Wales, —/KF852356/KF851619/KF852515; Mastigolejeunea auriculata (Wilson) Steph., Shaw 6222 (DUKE), USA: Alabama, KF851917/ KF852359/KF851622/KF852518; Neohattoria herzogii (S.Hatt.) Kamim., Furuki 22673 (F), Japan: Honshu, KM817504*/KM817530*/KM817557*/KM817484*; Nipponolejeunea pilifera (Steph.) S.Hatt., Ohnishi 5975 (HIRO), Japan, AM396291/ AM392293/—/—; Nipponolejeunea subalpina (Horik.) S.Hatt., Ohnishi 5611 (GOET), Japan, AM396290/AM392292/—/—; Odontolejeunea lunulata (F.Weber) Schiffn., Picon et al. 00227/CE (F), Venezuela, —/KM817514*/KM817537*/ KM817463*; Ptychanthus striatus (Lehm.) Nees, Pócs \& Pócs 03288/O (F), Fiji, KF851872/KF852318/KF851558/KF852460; Radula buccinifera (Hook.f. \& Taylor) Taylor ex Gottsche, Lindenb. \& Nees, Engel, von Konrat \& Braggins 23569 (F), New Zealand, KM817495*/KM817521*/KM817545*/KM817472*; Radula cuspidata Steph., Engel \& von Konrat 23517 (F), New Zealand, KM817496*/_/KM817546*/ KM817473*; Radula grandis Steph., Engel, von Konrat \& Braggins 24847 (F), New Zealand, KM817494*/KM817520*/KM817544*/KM817471*; Radula lindenbergiana Gottsche ex C.Hartm., Stotler 4656 (SIU), Portugal, KM817503*/KM817529*/ KM817556*/KM817483*; Radula perrottetii Gottsche ex Steph., Mizutani 15030 (F), Japan, —/DQ439700/KM817551*/KM817478*; Radula ratkowskiana K.Yamada, Engel, von Konrat \& Braggins 24365 (F), New Zealand, KM817497*/KM817522*/_/ KM817474*; Radula tasmanica Steph., Engel, von Konrat \& Braggins 24874 (F), New Zealand, KM817493*/KM817519*/_/KM817470*; Spruceanthus thozetianus (Gottsche \& F.Muell.) B.M.Thiers \& Gradst., Pócs 01107/M (GOET), Australia, 
AM396273/AM384877/_/_; Stictolejeunea squamata (Willd. ex F.Weber) Schiffn., Dauphin \& Gonzalez 2134 (GOET), Costa Rica: Alajeula, KF851951/_/_/ KF852549; Thysananthus convolutus Lindenb., Gradstein 10205 (GOET), Indonesia: Java, KF851953/DQ983737/KF851650/KF852551.

\section{Appendix 2}

Voucher information for data set 2. Information is presented in the following order: taxon name, collector followed by collection number (herbarium acronyms follow Holmgren et al. 1990), country: region (if known), GenBank accesion numbers (ITS region/rbcL/trnL-F/psbA). Lacking sequences are indicated by a dash (-). New sequences generated for this study are marked by an asterisk $(*)$.

Frullania kunzei (Lehm.) Lehm. \& Lindenb., Costa \& Gradstein 3769 (GOET), Brazil, FJ380536/FJ380863/FJ380387/FJ380697; Frullania nisquallensis Sull., Doyle 11001 (GOET), USA, FJ380503/FJ380826/FJ380349/FJ380661; Frullania peruviana Gottsche, Schaefer-Verwimp \& al. 24356 (GOET), Ecuador, FJ380543/ FJ380870/FJ380394/FJ380704; Frullanoides mexicana van Slageren, Burghardt 4421a, Mexico, DQ987366/DQ983682/DQ987464/EF011851; Fulfordianthus pterobryoides (Spruce) Gradst., Dauphin 2518, Costa Rica, AM237145/DQ983684/ AM237198/EF011832; Jubula hutchinsiae (Hook.) Dumort., Ahonen, Huttunen et Virtanen 3190 (H), Taiwan, AY125350/AY125946/AY144477/—; Jubula hutchinsiae subsp. bogotensis (Steph.) Verd. 1, Gradstein s.n. (GOET), Mexico: Veracruz, FN396818/—FN398013/—; Jubula hutchinsiae subsp. bogotensis 2, Gradstein s.n. (GOET?), Mexico, DQ987273/AY548100/DQ987388/AM396281; Jubula hutchinsiae subsp. bogotensis 3, Gradstein 9449 (GOET), Costa Rica, FN396817/_l FN398012/—; Jubula hutchinsiae subsp. bogotensis 4, Frahm et al. 1313 (GOET), Peru, FN396816/_/_/_; Jubula hutchinsiae subsp. caucasica Konstant. \& Vilnet 1, Konstantinova K456-5-07 (KPABG), Russia: Caucasus, JN836964/-l JN836974/—; Jubula hutchinsiae subsp. caucasica 2, Konstantinova K429-3-08 (KPABG), Russia: Caucasus, JN836961/—/JN836971/—; Jubula hutchinsiae subsp. caucasica 3, Konstantinova K462-1-08 (KPABG), Russia: Caucasus, JN836960/—/ JN836970/—; Jubula hutchinsiae subsp. caucasica 4, Konstantinova K463-1-07 (KPABG), Russia: Caucasus, JN836962/_/JN836972/—; Jubula hutchinsiae subsp. caucasica 5, Konstantinova K371-1-08 (KPABG), Russia: Caucasus, JN836958/-1 JN836968/-; Jubula hutchinsiae subsp. caucasica 6, Konstantinova K446-7-08 (KPABG), Russia: Caucasus, JN836959/—/JN836969/_; Jubula hutchinsiae subsp. caucasica 7, Konstantinova K443-14-08 (KPABG), Russia: Caucasus, JN836963/-l JN836973/—; Jubula hutchinsiae subsp. hutchinsiae 1, Long 29077 (GOET), UK: Devon, FN396813/_/FN398010/_; Jubula hutchinsiae subsp. hutchinsiae 2, Long 35296 (GOET), UK: Wales, FN396814/_/FN398011/—; Jubula hutchinsiae subsp. hutchinsiae 3, Schaefer-Verwimp \& Verwimp 25675 (GOET), Portugal: Madeira, FN396811/_/FN397099/_; Jubula hutchinsiae subsp. hutchinsiae 4, Schaefer- 
Verwimp \& Verwimp 25796 (GOET), Portugal: Boaventura, FN396812/—/ FN398009/—; Jubula hutchinsiae subsp. hutchinsiae 5, Drehwald \& Reiner-Drehwald 3007 (GOET), Portugal, DQ987260/AY548101/DQ987380/AM396282; Jubula hutchinsiae subsp. japonica (Steph.) Horik. \& Ando 1, Koponen et al. $54308(\mathrm{H})$, China, AY125342/AY125938/AY144479/_; Jubula hutchinsiae subsp. japonica 2, Inoue BSE755 (GOET), Japan: Kochi, FN396809/_/_/_; Jubula hutchinsiae subsp. japonica 3, Gradstein \& Mizutani 2958 (GOET), Japan: Miyazaki, FN396810/—/ FN397098/—; Jubula hutchinsiae subsp. japonica 4, Bakalin P-68-10-08 (KPABG), Russia: Primorsky Kray, JN836967/_/JN836977/_; Jubula hutchinsiae subsp. javanica (Steph.) Verd. 1, Zhu et al. 3361 (HSNU), China: Hainan, FN396800/_/_ I-; Jubula hutchinsiae subsp. javanica 2, Zhu et al. 20050903-7a (HSNU), China: Hainan, FN396801/_/_/_; Jubula hutchinsiae subsp. javanica 3, Long 34765 (GOET), China: Yunnan, FN396805/—/FN397095/—; Jubula hutchinsiae subsp. javanica 4, Pocs 98105/C (GOET), Viet Nam: Vin-Phuc, FN396807/_/_/—; Jubula hutchinsiae subsp. javanica 5, Pocs \& Tran Ninh 98103/A2 (GOET), Viet Nam: Vin-Phuc, FN396808/_/FN397097/—; Jubula hutchinsiae subsp. javanica 6, Schaefer-Verwimp \& Verwimp 18870/A (GOET), Malaysia: Pahang, FN396802/_l FN397094/-; Jubula hutchinsiae subsp. javanica 7, Zhu 555 (HSNU), China: Fujian, FN396806/_/FN397096/_; Jubula hutchinsiae subsp. javanica 8, Bakalin Kor12-6-08 (KPABG), South Korea, JN836966/—/JN836976/—; Jubula hutchinsiae subsp. javanica 9, Schaefer-Verwimp \& Verwimp 18935 (GOET), Malaysia: Pahang, FN396803/_/_/_; Jubula hutchinsiae subsp. javanica 10, Wang 685B (HSNU), China: Yunnan, FN396804/_/_-; Jubula hutchinsiae subsp. pennsylvanica (Steph.) Verd. 1, Buck 39060 (H?), USA: West Virginia, AY776308/AY776303/ AY776309/_; Jubula hutchinsiae subsp. pennsylvanica 2, Davison 5045 (UNAF), USA: Alabama, FN396819/_/_/_; Jubula hutchinsiae subsp. pennsylvanica 3, Davison 5201 (UNAF), USA: West Virginia, FN396821/_/FN398015/—; Jubula butchinsiae subsp. pennsylvanica 4, Davison 4707 (UNAF), USA: Alabama, FN396822/—I FN398016/—; Jubula hutchinsiae subsp. pennsylvanica 5, Davison 3775a (UNAF), USA: Alabama, FN396823/—FN398017/_; Jubula hutchinsiae subsp. pennsylvanica 6, Davison \& Risk 2537 (UNAF), USA: Kentucky, FN396820/—/FN398014/—; Jubula hutchinsiae subsp. pennsylvanica 7, Konstantinova ACH-3-92 (KPABG), USA, JN836965/—/JN836975/—; Jubula hutchinsiae subsp. pennsylvanica 8, Davison 4690 (UNAF), USA, Alabama, FN396824/_/FN398018/—; Jubula hutchinsiae subsp. pennsylvanica 9, Hyatt 8212 (UNAF), USA: North Carolina, FN396825/-1 FN398019/—; Jubula hutchinsiae subsp. pennsylvanica 10, Davison s.n. (UNAF), USA: North Carolina, FN396826/_/FN398020/_; Neohattoria herzogii (S.Hatt.) Kamim., Furuki 22673 (F), Japan: Honshu, KM817455*/KM817530*/KM817505*/ KM817504*; Nipponolejeunea pilifera (Steph.) S.Hatt. 1, Ohnishi 5975 (HIRO), Japan, _/AM392293/FJ380228/AM396291; Nipponolejeunea pilifera 2, Higuchi 41359 (H?), Japan, AY776307/AY776304/AY776310/—; Nipponolejeunea pilifera 3, Masuzaki 510 (HIRO), Japan: Yakushima Is., —/AB476588/—I—; Nipponolejeunea pilifera 4, Ohnishi s.n. (H), Japan, AY125341/AY125937/AY144478/—; Nippon- 
olejeunea subalpina (Horik.) S.Hatt. 1, Ohnishi 5611 (HIRO), Japan, DQ987289/ AM392292/FJ380227/AM396290; Nipponolejeunea subalpina 2, Higuchi 41358 (H?), Japan, AY776306/AY776305/AY776311/—; Ptychanthus striatus (Lehm.) Nees, Gradstein 10217, Indonesia: Java, DQ987297/DQ983723/DQ987403/EF011777; Schiffneriolejeunea nymannii (Steph.) Gradst. \& Terken, Gradstein et al. 10321, Malaysia, DQ987320/DQ983725/DQ987424/EF011801. 